\title{
ANALISIS PELAKSANAAN PROGRAM PENGENDALIAN PENYAKIT DEMAM BERDARAH DENGUE (P2DBD) DI WILAYAH KERJA UPT PUSKESMAS BENGKALIS KABUPATEN BENGKALIS TAHUN 2020
}

\author{
Bima Umbara ${ }^{1}$, Raviola ${ }^{2}$ \\ Sarjana Kesehatan Masyarakat STIKes Hang Tuah \\ bimaumbara11@gmail.com¹, raviola@htp.ac.id²
}

\begin{abstract}
Dengue hemorrhagic fever is an infection caused by the dengue virus. Dengue is a disease virus transmitted from the Aedes aegypti mosquito. Based on data from the Ministry of Health, in 2019 there were 935 cases of dengue fever cases in Bengkalis Regency. The purpose of this study in general is to obtain information about the analysis of the implementation of the DHF disease control program, with variables of human resources, funds, facilities and infrastructure, methods / standard operating procedures, epidemiological investigations, periodic larva checks, counseling, and fogging. The type of research used is descriptive qualitative, with 6 informants. From the results of the research there was success in implementing fogging and epidemiological investigations in accordance with standard operating procedures, and there were several constrained programs, namely from human resources where the P2DBD program holder was held by 1 person who concurrently had his job. The availability of funds is hampered because they have to wait for the APBD to be disbursed, so if there is a shortage of funds when they go down, they must use the puskesmas funds. Less facilities and infrastructure in terms of fogging and abate. Periodic larva checks were hampered, and counseling was hampered due to the pandemic where it was difficult for the puskesmas to gather the masses in providing counseling for dengue kicking. From the research results it can be concluded that the lack of facilities and infrastructure in the availability of abate, the lack of maximum counseling, funds, and periodic larva checks are factors in the increase in dengue hemorrhagic fever in the UPT Puskesmas Bengkalis Work Area in 2020. The puskesmas should increase the availability of facilities and infrastructure, performance of jumantik cadres and maximizing the use of funds in order to reduce the incidence of dengue fever in the working area of the UPT Puskesmas Bengkalis, Bengkalis Regency.
\end{abstract}

\section{Keywords}

: Analysis, DHF Control Program, UPT

\begin{abstract}
ABSTRAK
Penyakit Demam Berdarah dengue adalah infeksi yang di sebabkan oleh virus dengue. Dengue adalah virus penyakit yang ditularkan dari nyamuk Aedes aegypti. Berdasarkan dari data Kementerian kesehatan, pada tahun 2019 kasus kejadian DBD di Kabupaten Bengkalis dengan jumlah penderita 935 kasus kejadian DBD. Tujuan dari penelitian ini secara umum untuk memperoleh informasi tentang analisis pelaksanaan program pengendalian penyakit DBD, dengan variabel sumber daya manusia, dana, sarana dan prasarana, metode / standar operasional prosedur, penyelidikan epidemiologi, pemeriksaan jentik berkala, penyuluhan, dan fogging. Jenis penelitian yang digunakan berupa deskriptif kualitatif, dengan jumlah informan 6 orang. Dari hasil penelitian ada keberhasilan dalam pelaksanaan fogging dan penyelidikan epidemiologi yang sesuai dengan standar operasional prosedur, dan ada beberapa program yang terkendala yaitu dari sumber daya manusia dimana pemegang program P2DBD dipegang oleh 1 orang yang merangkap pekerjaannya. Ketersediaan dana
\end{abstract}


yang terhambat karena harus menunggu pencairan APBD sehingga jika kekurangan dana saat turun kelapangan harus menggunakan dana puskesmas. Sarana dan prasarana yang kurang dari segi fogging dan abate. Pemeriksaan jentik berkala yang terkendala, dan penyuluhan yang terhambat akibat pandemi yang dimana pihak puskesmas sulit untuk mengumpulkan massa dalam pemberian penyuluhan tendang DBD. Dari hasil penelitian dapat disimpulkan bahwa kurangnya sarana dan prasarana dalam ketersediaan abate, kurang maksimal nya penyuluhan, dana, dan pemeriksaan jentik berkala merupakan faktor terjadinya peningkatan penyakit demam berdarah dengue di Wilayah Kerja UPT Puskesmas Bengkalis tahun 2020. Hendaknya pihak puskesmas dapat meningkatkan ketersediaan sarana dan prasarana, kinerja kader jumantik dan memaksimalkan penggunaan dana agar dapat menekan angka kejadian DBD di wilayah kerja UPT Puskesmas Bengkalis Kabupaten Bengkalis.

Kata Kunci $\quad$ : Analisis, Program Pengendalian DBD, UPT

\section{PENDAHULUAN}

Demam Berdarah Dengue (DBD) adalah infeksi yang di sebabkan oleh virus dengue. Dengue adalah virus penyakit yang ditularkan dari nyamuk Aedes Spp, nyamuk yang paling cepat berkembang di dunia ini telah menyebabkan hampir 390 juta orang terinfeksi setiap tahunnya. Beberapa jenis nyamuk menularkan atau menyebarkan virus dengue. DBD memiliki gejala serupa dengan Demam dengue, namun DBD memiliki gejala lain berupa sakit / nyeri pada ulu hati terus-menerus. Pendarahan pada hidung, mulut, gusi atau memar pada kulit. (Kementrian Kesehatan RI, 2018).

Demam Berdarah Dengue masih menjadi permasalahan kesehatan baik di wilayah perkotaan maupun wilayah semiperkotaan. Perilaku vektor dan hubungannya dengan lingkungan, seperti iklim, pengendalian vektor, urbanisasi, dan lain sebagainya mempengaruhi terjadinya wabah demam berdarah di daerah perkotaan. Belum ada prediksi yang tepat untuk menunjukkan kehadiran dan kepadatan vektor (terutama Aedes Aegypti di lingkungan perkotaan dan semi perkotaan). Penyebaran dengue dipengaruhi faktor iklim seperti curah hujan, suhu dan kelembaban. Kelangsungan hidup nyamuk akan lebih lama bila tingkat kelembaban tinggi, seperti selama musim hujan (Nazri,
Hashim, Rodziah, Hassan, \& Yazid, 2013). Program P2DBD adalah semua upaya untuk mencegah dan menangani kejadian DBD termasuk tindakan untuk membatasi penyebaran penyakit DBD. Mengingat nyamuk ini telah tersebar luas di seluruh Indonesia, baik di rumah-rumah maupun di tempat-tempat umum, maka upaya pencegahan tidak hanya merupakan tugas pemerintah (tenaga kesehatan) saja tetapi harus didukung oleh peran serta masyarakat. Pelaksanaan Program P2DBD ini harus diiringi dengan adanya kegiatan supervisi dan bimbingan teknis.

Upaya pemberantasan penyakit demam berdarah dengue dilaksanakan dengan cara pelaksanaan kegiatan pengendalian DBD yaitu: Surveillants Epidemiologi, Penemuan dan Tata laksana Kasus, Pengendalian Vektor, peningkatan peran serta masyarakat, sistem kewaspadaan dini dan penanggulangan KLB, penyuluhan, kemitraan/jejaring kerja, pengembangan SDM, penelitian dan survey, Monitoring dan evaluasi. Upaya pemberantasan DBD difokuskan pada penggerakan potensi masyarakat untuk berperan serta dalam Pemberantasan Sarang Nyamuk DBD (PSN DBD) melalui 4M Plus (4M: menguras, menutup, mendaur ulang barang bekas, mengubur dan plus: menabur larvasida (abatisasi), memelihara ikan pemakan jentik, memakai kawat kasa, menghindari menggantung 
pakaian di dalam kamar, mengenakan kelambu dan memakai obat/lotion anti nyamuk) (Kemenkes, 2011).

Hasil penelitian (Zumaroh, 2015), mengatakan bahwa identifikasi permasalahannya yaitu diperlukan suatu perencanaan program P2DBD di mana semua para pemegang program $\mathrm{P} 2 \mathrm{DBD}$ dapat bersinergi dengan baik dalam upaya keberhasilan pencegahan dan penanggulangan penyakit DBD. Pencegahan dan penanggulangan DBD diupayakan dari segi preventif yaitu dengan memutus mata rantai penularan DBD. Untuk itu diperlukan sebuah manajemen Program Pengendalian Penyakit DBD (P2DBD) agar bisa menekan jumlah kasus dan angka kesakitan DBD. Program tersebut dapat terlaksana dengan baik atau tidak sangat dipengaruhi oleh peran serta dari seluruh pihak seperti pejabat setempat, petugas kesehatan dan seluruh lapisan masyarakat.

Penyakit Demam Berdarah Dengue (DBD) sampai saat ini masih merupakan suatu permasalahan kesehatan di Provinsi Riau yang memerlukan perhatian serius dari semua pihak, mengingat penyakit ini sangat berpotensi menjadi Kejadian Luar Biasa (KLB) dan merupakan ancaman besar bagi masyarakat luas. Di Provinsi Riau, jumlah kasus DBD yang dilaporkan pada tahun 2017 dilaporkan sebanyak 1871 (incidence rate $=50,7$ per 100.000 penduduk) dan angka kematian sebanyak 18 orang. Sedangkan pada tahun 2018, penderita demam berdarah mengalami penurunan dengan jumlah kasus yang dilaporkan sebanyak 1140 (incidence rate $=31,26$ per 100.000 penduduk) dan angka kematian sebanyak 7 orang. Sedangkan pada tahun 2019, penderita demam berdarah mengalami pelonjakan angka yang signifikan dengan jumlah kasus penderita yang dilaporkan sebanyak 4345 kasus (incidence rate $=86,64$ per 100.000 penduduk) dan meninggal sebanyak 31 orang. (Pusdatin-Kemkes RI, 2020).

Dari hasil wawancara awal dengan kepala Puskesmas Bengkalis Kecamatan
Bengkalis diketahui bahwa masih kurangnya tingkat kesadaran masyarakat tentang pentingnya pengendalian Penyakit DBD ini serta kendala pelaksanaan program pengendalian penyakit Demam Berdarah. Menurut beliau, hal tersebut dikarenakan Penyelidikan Epidemiologi (PE) masih terjadi kendala dimana petugas sulit melacak atau menemukan lokasi penderita serta masyarakat yang terkena penyakit DBD tidak melapor sehingga menyulitkan petugas untuk melakukan kegiatan Penyelidikan Epidemiologi. Beliau juga mengatakan bahwa Faktor Tenaga juga menjadi masalah di bidang Surveilens. Menurut petugas surveilens bidang epidemiologi, di Puskesmas mereka memiliki pekerjaan yang merangkap, sehingga tidak fokus kepada Program Pengendalian Demam Berdarah Dengue. Dari uraian latar belakang di atas, Peneliti tertarik untuk melakukan penelitian tentang "Analisis Pelaksanaan Program Pengendalian Penyakit Demam Berdarah Dengue di Wilayah Kerja UPT Puskesmas Bengkalis Kabupaten Bengkalis".

\section{METODE}

Jenis penelitian ini merupakan penelitian kualitatif dan metode deskriptif. Penggunaan jenis kualitatif ini dipilih yang bertujuan untuk memudahkan penyesuaian apabila berhadapan dengan pernyataan ganda, lebih peka dan lebih dapat di sesuaikan untuk menganalisis Pelaksanaan Program

Pengendalian Demam Berdarah Dengue (P2DBD) Di Wilayah Kerja UPT Puskesmas Bengkalis Kota Bengkalis Tahun 2020. Penelitian ini akan dilaksanakan di wilayah kerja UPT Puskesmas Bengkalis Kabupaten Bengkalis yang akan dilakukan pada bulan Juni-Juli 2020. Informan yang dipilih adalah informan yang mengetahui permasalahan dengan jelas, dapat dipercaya untuk menjadi sumber data yang baik serta mampu mengemukakan 
pendapat secara baik dan benar (Notoadmodjo, 2005), Jumlah informan ada 6 orang dengan kriteria mengetahui permasalahan dengan jelas dan memiliki peran dalam pelaksanaan program demam berdarah dengue. Dimana informan yang terpilih untuk penelitian ini adalah seperti pada Tabel 1 berikut ini:

Tabel 1 Informan Penelitian

\begin{tabular}{clccc}
\hline No & Informan & Kategori & Jumlah & $\begin{array}{c}\text { Kode } \\
\text { Informan }\end{array}$ \\
\hline 1 & $\begin{array}{l}\text { Kepala } \\
\text { Puskesmas } \\
\text { Bengkalis. }\end{array}$ & Utama & $\begin{array}{c}1 \\
\text { orang }\end{array}$ & IU 1 \\
\hline \multirow{2}{*}{$\begin{array}{l}\text { Pemegang } \\
\text { Program } \\
\text { P2DBD }\end{array}$} & Utama & $\begin{array}{c}1 \\
\text { orang }\end{array}$ & IU 2 \\
\hline 3 & $\begin{array}{l}\text { Kasubag } \\
\text { Tata Usaha }\end{array}$ & $\begin{array}{c}\text { Pendukun } \\
\text { g }\end{array}$ & $\begin{array}{c}1 \\
\text { orang }\end{array}$ & IP 1 \\
\hline 4 & $\begin{array}{l}\text { Kader } \\
\text { Jumantik }\end{array}$ & $\begin{array}{c}\text { Pendukun } \\
\text { g }\end{array}$ & $\begin{array}{c}1 \\
\text { orang }\end{array}$ & IP 2 \\
\hline 5 & $\begin{array}{l}\text { Kader } \\
\text { Jumantik }\end{array}$ & $\begin{array}{c}\text { Pendukun } \\
\text { g }\end{array}$ & $\begin{array}{c}1 \\
\text { orang }\end{array}$ & IP 3 \\
\hline 6 & $\begin{array}{l}\text { Kader } \\
\text { Jumantik }\end{array}$ & $\begin{array}{c}\text { Pendukun } \\
\text { g }\end{array}$ & $\begin{array}{c}1 \\
\text { orang }\end{array}$ & IP 3 \\
\hline \multicolumn{1}{c}{ Total $=$} & 6 orang & \\
\hline
\end{tabular}

\section{HASIL}

\section{Sumber Daya Manusia}

Berdasarkan hasil wawancara mendalam dengan berbagai narasumber mengenai Sumber Daya Manusia yang ada dalam program $\mathrm{P} 2 \mathrm{DBD}$, di ketahui bahwa dalam struktur organisasi program P2DBD puskesmas, terdapat 1 Penanggung Jawab program P2DBD, yang dimana ia merangkap kerja sebagai penanggung jawab Penyelidikan Epidemiologi, fogging, dan Penyuluhan. Dan 1 orang anggota yang menjadi penanggung jawab program Pemeriksaan Jentik Berkala. Dibantu dengan beberapa pekerja puskesmas yang tergabung untuk menjalankan program P2DBD ini dan juga sudah mendapatkan pelatihan.

Dari Sumber Daya Manusia yang ada dalam program P2DBD, diketahui bahwa penanggung jawab program
P2DBD, berlatar belakang pendidikan keperawatan, sedangkan petugas yang tergabung dalam tim, ada yang latar belakang pendidikan nya perawat, dan ada juga tamatan SLTA.

Berdasarkan hasil wawancara mendalam, untuk meningkatan kualitas Sumber Daya Manusia, para petugas puskesmas yang tergabung dalam P2DBD, sudah mendapatkan pelatihan mengenai program pengendalian penyakit demam berdarah, dan juga para kader jumantik telah di berikan pelatihan agar dapat meningkatkan kulitas sumber daya manusia di puskesmas.

\section{Dana}

Berdasarkan dari hasil wawancara mendalam mengenai pendanaan kegiatan program P2DBD, di ketahui bahwa untuk kegiatan P2DBD, sumber dana di peroleh dari APBD, dan juga dari Bantuan Operasional Kesehatan (BOK), namun dikarenakan pencairan dana APBD termasuk lama, sehingga pihak puskesmas memutuskan untuk menggunakan dana kas puskesmas itu sendiri, dan juga menggunakan dana pribadi dari pemegang program tersebut, sehingga jika dana APBD sudah keluar, baru di kembalikan dana yang telah terpakai.

Tidak hanya di anggaran, hambatan yang lain juga terdapat dalam Pendanaan kegiatan P2DBD. Di akibatkan karena keterbatasan biaya dalam kegiatan P2DBD.

\section{Sarana dan Prasarana}

Berdasarkan hasil wawancara mengenai sarana dan prasarana yang ada di Puskesmas Bengkalis, diketahui bahwa semua perlengkapan alat dan bahan untuk turun kelapangan sudah ada tersedia di Puskesmas mencakup alat fogging, data, dan alat pelindung diri.

Namun ketersediaan alat fogging yang sangat minim, sehingga sulit untuk memaksimalkan pengerjaan dalam kegiatan P2DBD dikarenakan hanya 
ada 1 alat fogging yang dapat digunakan pada saat turun ke lapangan.

\section{Metode / Standar Operasional Prosedur}

Berdasarkan dari hasil wawancara dan juga menelusuri dokumen Standar Operasional Prosedur yang ada di puskesmas, dapat dilihat dan diketahui bahwa, setiap kegiatan sudah dilakukan sesuai dengan standar operasional prosedur.

Dan diketahui bahwa semua kegiatan dapat berjalan dengan baik dan sesuai dengan standar operasional prosedur.

\section{Pelaksanaan}

\section{Penyelidikan Epidemiologi}

Dari hasil wawancara mendalam mengenai Penyelidikan Epidemiologi, diketahu bahwa kegiatan Penyelidikan Epidemiologi di laksanakan apabila ada laporan dari pihak rumah sakit jika pasien terkonfirmasi terserang penyakit demam berdarah. Sehingga pihak puskesmas pun segera melakukan tindakan preventif.

Namun terdapat kendala yang dihadapi pihak Puskesmas terkait dalam kegiatan penyelidikan epidemiologi ini yang dimana masyarakat kurang bisa menerima kehadiran petugas untuk melakukan penyelidikan epidemiologi.

\section{Pemeriksaan Jentik Berkala}

Diketahu bahwasannya, pelaksanaan Pemeriksaan Jentik Berkala pada tahun 2019 mengalami kendala yaitu kegiatan PJB tidak berjalan dengan baik.

\section{a. Penyuluhan}

Kegiatan penyuluhan tidak dapat berjalan dengan baik dikarenakan terkendala oleh pandemi, sehingga pihak puskesmas tidak dapat melanjutkan kegiatan penyuluhan. Namun alternatif lain dari penyuluhan yang mengumpulkan massa, pihak Puskesmas memberikan penyuluhan dengan cara memberikan sedikit penyuluhan pada saat melakukan kegiatan fogging.

\section{b. Fogging}

Dalam kegiatan fogging, pihak puskesmas akan melaksanakan kegiatan fogging apabila dalam Penyelidikan Epidemiologi mendapatkan hasil positif jentik DBD nya telah didapat.

Diketahui bahwa dalam kegiatan fogging, terdapat 4 sampai 6 orang yang turun untuk melaksanakan kegiatan fogging.

Dan diketahui bahwa dalam kegiatan fogging, terdapat kendala dimana masyarakat enggan untuk dilakukan penyemprotan di dalam rumah, yang dimana proses pembasmian tempat bersarang nyamuk tidak akan maksimal.

\section{PEMBAHASAN}

\section{Sumber Daya Manusia}

Asumsi dari peneliti adalah dengan merangkapnya jabatan dalam 1 pekerjaan, hanya akan mempersulit kinerja penanggung jawab program, walaupun kegiatan dibantu oleh tenaga kesehatan, namun akan tetap mempengaruhi kinerja penanggung jawab program yang dimana ia sebagai penanggung jawab program, penyelidikan epidemiologi, fogging, dan juga promosi kesehatan, sehingga akan tidak terfokus pekerjaannya.

Hasil penelitian Anita (2016), diperoleh persentase indikator terhadap ketersediaan Sumber Daya Manusia (SDM) memenuhi $75 \%$ atau memenuhi 3 dari 4 indikator dari Kepmenkes RI Nomor 581/ MENKES/SK/VII/1992 yang meliputi dokter umum, perawat, dan kader. Hasil penelitian Sari (2013), Sumber Daya Manusia (SDM) pada pelaksanaan kegiatan program Pemberantasan Penyakit DBD (P2DBD) dari segi jumlah dan luas wilayah sudah cukup. Dari segi kualitas diperoleh petugas dengan kualifikasi yang baik dan pengalaman selama bertahuntahun. Hasil penelitian Kusumo (2014), 
Apabila dilihat dari uraian tugas masingmasing petugas jumlah tenaga untuk program pengendalian DBD dikatakan cukup.

Sumber Daya Manusia (SDM) di Dinas Kesehatan Provinsi Sumatera Utara tidak terjadi rangkap tugas, sedangkan di Kabupaten/Kota kemungkinan terjadi rangkap tugas. Hal ini berbanding terbalik dengan penelitian Mufidz (2016) bahwa terdapat rangkap tugas pada kepala seksi pemberantasan penyakit DBD. Petugas yang mengerjakan tugas rangkap menyebabkan kegiatan program tidak sesuai dengan optimal karena ada pembagian waktu tugas yang singkat dengan pekerjaan yang banyak (Frans, 2010).

\section{Dana}

Dari hasil kesimpulan wawancara di atas, asumsi dari peneliti adalah walaupun terkendala dalam pencairan dana, kegiatan P2DBD dapat berjalan dengan baik apabila tidak terkendala dalam permasalahan pendanaan. Sehingga setiap kegiatan P2DBD yang membutuhkan dana, dapat langsung berjalan tanpa harus menunggu pencairan dana dari APBD.

Berdasarkan penelitian (Izzah dkk, 2019). Dana untuk program DBD (Demam Berdarah Dengue) di Dinas Kesehatan Provinsi Sumatera Utara hanya bersumber dari dana APBD (Anggaran Pendapatan dan Belanja Daerah) serta belum adanya dana APBN (Anggaran Pendapatan dan Belanja Negara) dan dana BOK (Bantuan Operasional Kesehatan). Dalam kurun waktu 3 tahun terakhir, tidak ada kembali dana APBN (Anggaran Pendapatan dan Belanja Negara) untuk program DBD di Dinas Kesehatan Provinsi Sumatera Utara, sedangkan beberapa program kesehatan lainnya menerima dana APBN (Anggaran Pendapatan dan Belanja Negara). Dana APBD (Anggaran Pendapatan dan Belanja Daerah) yang diterima tahun 2018 hanya sekitar Rp. 200 juta, sedangkan dana yang seharusnya diterima lebih dari Rp. 1 Miliar.

Keterbatasan dana pada program DBD (Demam Berdarah Dengue) di Dinas Kesehatan Provinsi Sumatera Utara memiliki implikasi terhadap tidak maksimalnya pelaksanaan salah satu kegiatan yaitu "Gerakan satu rumah satu Jumantik", sehingga hanya dilakukan kunjungan dan sosialisasi ke daerah sasaran serta tidak dilakukan kerja sama lintas sektor pada kegiatan tersebut. Kerjasama lintas sektor program DBD dilakukan dengan instansi pendidikan, dan lingkungan. Dilakukan maksimal dua kali dengan kegiatan hanya pengarahan pada kabupaten yang menyelenggarakan. Kerja sama lintas sektor hanya tertuang pada SK (Surat Keputusan) tanpa mengaplikasikan di lapangan. Kerja sama lintas sektor Dinas Kesehatan Provinsi Sumatera Utara adalah POKJANAL (Kelompok Kerja Operasioanal) DBD wilayah Sumatera Utara yang pada akhirnya selalu hanya dilaksanakan oleh Dinas Kesehatan Provinsi Sumatera Utara (Izzah dkk, 2019). Berdasarkan hasil penelitian putri, (2017) yang menyatakan dana yang kurang untuk program pemberantasan DBD dengan sumber dana berasal dari Pemerintah Kota dan APBD (Anggaran Pendapatan dan Belanja Daerah). Penelitian Sitepu (2012) menyebutkan dana APBD dialokasikan secara periode bersifat fluktuatif dan lebih banyak diprioritaskan pada hal teknis. Hal serupa dengan penelitian Sriwulandari (2009) bahwa kurangnya anggaran dana dari APBD pada pelaksanaan Program Pencegahan dan Penanggulangan Penyakit DBD di Dinkes Kabupaten Magetan.

\section{Sarana dan Prasarana}

Asumsi dari peneliti adalah masih kurangnya sarana dan prasarana baik dari sisi mesin fogging yang dimiliki hanya 1 sehingga pekerjaan tidak dapat di selesaikan dengan cepat dan juga dari abate yang stok nya kosong. Saran dari peneliti adalah alangkah baiknya bila mesin fogging di tambah lagi dan juga 
perlu adanya peningkatan akan ketersediaan abate tersebut. Bila perlu diadakannya abate secara mandiri dari pihak Puskesmas.

\section{Berdasarkan Kepmenkes RI Nomor 581/ MENKES/SK/VII/1992 tentang} Pemberantasan Penyakit Demam Berdarah Dengue, sarana dan bahan yang digunakan, yaitu mesin fogging dengan kebutuhannya setiap puskesmas sebanyak 4 unit, setiap kabupaten/kota sebanyak 10 unit, dan setiap provinsi sebanyak 10 unit, mesin ULV (Ultra-Low Volume), kendaraan pengangkut ULV (Ultra-Low Volume), kebutuhannya setiap kabupaten, kotamadya, dan provinsi sebanyak 2 unit, kebutuhan PSN kit dan kebutuhan Jumantik (Juru Pemantau Jentik), insektisida, larvasida, dan bahan pendukung diagnosis lainnya serta penatalaksanaan penderita DBD (Depkes RI, 2011). Jika sarana dan prasarana yang dibutuhkan oleh tenaga pelaksana mengalami kekurangan, maka hal tersebut bisa menghambat jalannya pelaksanaan program yang mengakibatkan pencapaian target tidak sesuai dengan perencanaan. Oleh karena itu, sarana menjadi suatu hal yang harus tersedia dan harus dapat mencukupi sesuai dengan kebutuhan berdasarkan Kepmenkes RI Nomor 581/ MENKES/SK/VII/1992.

Berdasarkan hasil penelitian (Izzah dkk, 2019) sarana dan prasarana Dinas Kesehatan Provinsi Sumatera Utara memiliki batasan sebagai penunjang di tingkat Kabupaten/Kota seperti rapid test dan alat fogging. Untuk diagnosis penyakit DBD (Demam Berdarah Dengue), dilakukan pemeriksaan di laboratorium untuk identifikasi trombosit dan hematokrit. Pada program DBD (Demam Berdarah Dengue) Dinas Kesehatan Provinsi Sumatera Utara terdapat insektisida sebanyak 2 liter, rapid test 100 item, dan larvasida 300 botol. Indikator sarana dan prasarana tersebut sudah terpenuhi sebagai fasilitator kepada tingkat Kabupaten/Kota. Sarana dan prasarana digunakan untuk sosialisasi, kemudian jika ada kasus DBD (Demam Berdarah Dengue) akan dilaksanakan upaya fogging pada daerah sasaran.

Setiap program P2DBD memiliki sarana pendukung masing-masing. Sarana yang digunakan oleh Puskesmas Mojosongo adalah senter untuk mendukung pelaksanaan PSN, alat fogging, obat fogging, bahan bakar dan APD untuk mendukung pelaksanaan fogging, dan bubuk abate untuk pelaksanaan abatisasi. Dari segi kuantitas sarana pendukung program P2DBD di puskesmas sudah mencukupi kebutuhan, tetapi dari segi kualitasnya masih rendah terutama pada kegiatan PSN dan abatisasi (Anis Faizah dkk, 2018).

\section{Metode / Standar Operasional Prosedur}

Hasil kesimpulan dari wawancara mendalam dan juga observasi mengenai Standar Operasional Prosedur, asumsi dari peneliti adalah pihak puskesmas telah menjalankan setiap kegiatan mengikuti Standar Operasional Prosedur, namun ekspektasinya masih banyak kegiatan yang terkendala akibat dari faktor lain.

Berdasarkan penelitian dari Faizah dan kawan-kawan. Pada masing-masing program P2DBD yang ada di Puskesmas Mojosongo telah memiliki SOP. Di Kabupaten Boyolali belum ada kebijakan yang mengatur mengenai program P2DBD dan selama ini hanya berpedoman pada Renstra Kabupaten. Didalam pelaksanaan suatu program, dibutuhkan pengarahan terlebih dahulu dari atasan maupun penanggung jawab program untuk kelancaran dan keberhasilan didalam melaksanakan suatu program. Laporan dari puskesmas ke desa/kelurahan hanya secara lisan melalui pertemuan Pokjanal DBD setiap 3 atau 4 bulan sekali. Sebagai bukti bahwa telah dilaksanakan suatu program, maka diperlukan bukti terlaksananya suatu program berupa berita acara. Namun, petugas pelaksana di Puskesmas Mojosongo hanya membuat laporan hasil kegiatan berupa hasil monitoring. Selain itu, terdapat pelatihan yang diberikan 
untuk kader jumantik yang ada di desa/kelurahan berupa pemberian materi dan praktik oleh puskesmas dan DKK Boyolali (Anis Faizah dkk, 2018).

\section{Pelaksanaan}

\section{Penyelidikan Epidemiologi}

Asumsi dari peneliti adalah proses Penyelidikan Epidemiologi di puskesmas sudah berjalan dengan baik dan sesuai dengan SOP. Namun ketidak ramahan masyarakat menjadi kendala apabila petugas akan melaksanakan penyelidikan epidemiologi. Saran dari peneliti adalah hendaknya pihak Puskesmas lebih meningkatkan kerja sama antar lintas sektor, sehingga akan mempermudah kegiatan penyelidikan epidemiologi.

Hal ini serupa dengan hasil penelitian Faizah dan kawan-kawan. Kegiatan PE dilakukan apabila ditemukan penderita DBD yang sudah dinyatakan positif dengan surat keterangan yang dikeluarkan oleh pihak rumah sakit. Sebelum dilakukan kegiatan PE, pihak Puskesmas Mojosongo memberikan pemberitahuan ke desa/kelurahan yang terkait bahwa akan dilakukan kegiatan PE di wilayah tersebut berupa surat pemberitahuan dan surat untuk menjalankan tugas $\mathrm{PE}$ oleh petugas kesehatan. Pelaksanaan kegiatan PE dilakukan dengan memeriksa rumah penderita dan sekitarnya melalui bidan desa yang bertugas di wilayah tersebut. (Faizah, 2018).

Faktor-faktor yang mendukung dalam pelaksanaan kegiatan program $\mathrm{PE}$ adalah informasi yang valid dari berbagai sumber, kecepatan pelaporan, kesigapan petugas yang didukung dengan sarana prasarana, adanya hubungan baik antara petugas kesehatan dengan masyarakat, dan koordinasi lintas sektor dengan desa/kelurahan.

Berdasar hasil penelitian yang dilakukan oleh Rahayu (2012) yang menyatakan bahwa hasil kegiatan penyelidikan epidemiologi dan fogging fokus mempunyai hubungan yang bermakna dengan kejadian DBD.

Faktor-faktor yang mendukung dalam pelaksanaan kegiatan program PE adalah informasi yang valid dari berbagai sumber, kecepatan pelaporan, kesigapan petugas yang didukung dengan sarana prasarana, adanya hubungan baik antara petugas kesehatan dengan masyarakat, dan koordinasi lintas sektor dengan desa/kelurahan.

\section{Pemeriksaan Jentik Berkala}

Asumsi dari peneliti adalah kegiatan PJB tidak berjalan dengan baik di akibatkan oleh tiada pengawasan dari pihak puskesmas terhadap para kader jumantik. Sehingga para kader bisa saja tidak melaksanakan kegiatan PJB karena tidak ada pengawas. Saran dari peneliti adalah pihak puskesmas harus mengambil tindakan untuk ikut serta turun bersama para kader untuk dapat dipantau pekerjaan nya sehingga proses PJB akan berjalan dengan baik.

Berdasarkan dari penelitian (Faizah dan kawan-kawan). Kendala yang dialami Puskesmas Mojosongo didalam pelaksanaan kegiatan PJB ini tidak jauh berbeda dengan kendala kegiatan PSN, yaitu masih rendahnya kesadaran masyarakat, dana, dan masih kurangnya tenaga jumantik. Upaya yang telah dilakukan Puskesmas Mojosongo untuk mengatasi kendala tersebut adalah dengan mengadakan pelatihan untuk kader jumantik dan melakukan koordinasi lintas sektor dengan desa/kelurahan. Faktorfaktor yang dapat mendukung didalam pelaksanaan kegiatan PJB adalah dari segi tenaga yaitu kader jumantik, sarana prasarana, dan dana untuk fee kader jumantik.

Penelitian yang dilakukan oleh (Rosidi, 2009), menunjukkan bahwa ada hubungan yang bermakna antara pemantauan jentik secara berkala dan angka bebas jentik. Kenyataan di lapangan bahwa kegiatan PJB ini sangat efektif dalam upaya memotivasi masyarakat untuk 
untuk selalu melaksanakan gerakan PSNDBD dengan 3M.

\section{a. Penyuluhan}

Asumsi dari peneliti adalah walaupun kegiatan penyuluhan terpaksa diberhentikan akibat pandemi, langkah yang di ambil pihak puskesmas sudah sangat baik, namun apabila penyuluhan yang sederhana sudah dilakukan, tetapi masyarakat sendiri tidak menerapkan $4 \mathrm{M}$, maka usaha untuk menyadarkan masyarakat dengan cara penyuluhan akan terasa sia-sia. Saran dari peneliti adalah mengulang terus menerus pemberian penyuluhan tiap rumah masyarakat, sehingga pesan kesehatan yang telah diberikan akan mudah tersampaikan dan mudah dimengerti masyarakat.

Berdasarkan penelitian dari (Faizahdkk,2018) Informasi kesehatan yang berkaitan dengan DBD yang penting untuk disampaikan kepada masyarakat adalah mengenai pentingnya peran jumantik didalam memberantas penyakit DBD. Metode penyampaian informasi yang tepat untuk diterapkan yaitu dengan metode penyampaian informasi 2 arah yang didalam pelaksanaannya lebih ke arah workshop.

Berdasarkan hasil penelitian yang dilakukan oleh Resmiati (2009) tentang pengaruh penyuluhan demam berdarah terhadap perilaku ibu rumah tangga menunjukkan hasil bahwa penyuluhan kesehatan tentang demam berdarah efektif karena sangat signifikan terhadap tindakan.

Sedangkan hasil penelitian yang dilakukan oleh (Azwar,2010) Penyuluhan kesehatan masyarakat pada dasarnya bersifat penunjang untuk usaha kesehatan lainnya. Sekalipun bersifat penunjang bukan berarti usaha penyuluhan kesehatan masyarakat tidak perlu, karena sebenarnya lah berhasil atau tidaknya suatu usaha kesehatan ditentukan oleh baik atau tidaknya pelaksanaan usaha penyuluhan kesehatan masyarakat yang terpadu di dalamnya. Jika tingkat pengetahuan kurang, sikap bertentangan dengan prinsip hidup sehat serta tingkah laku berlawanan dengan konsep kesehatan, maka mudah dipahami bahwa derajat kesehatan masyarakat akan jauh dari memuaskan.

\section{b. Fogging}

Asumsi peneliti adalah kegiatan fogging akan terkendala jika tiada nya dana yang memadai. Dan juga apabila hanya 1 mesin fogging yang dapat digunakan, maka hasil nya akan kurang maksimal dikarenakan akan membutuhkan tenaga yang banyak apabila proses fogging itu harus mengelilingi segala arah. Saran dari peneliti adalah Akan lebih baik jika mesin fogging nya di tambah agar meringankan dan mempercepat proses pekerjaan fogging.

Pelaksanaan fogging dapat dilaksanakan dengan adanya faktor-faktor pendukung berupa ketersediaan SDM, transportasi, sarana dan prasarana yang memadai, serta dana yang mencukupi untuk dilaksanakannya fogging.

Menurut hasil penelitian Siti Hidayati (2005), pengetahuan masyarakat tentang fogging masih kurang dan persepsi masyarakat tentang fogging kurang baik karena fogging merupakan program yang lebih disenangi daripada program PSN DBD yang lain dengan alasan dilaksanakan dengan bersama-sama dan meninggalkan bekas/ada buktinya.

\section{KESIMPULAN}

Berdasarkan hasil penelitian dapat disimpulkan bahwa secara umum program pengendalian penyakit demam berdarah dengue di UPT Puskesmas Bengkalis mendapat kendala dalam sumber daya manusia yang dimana pemegang program penyakit Demam Berdarah Dengue ini hanya satu dan merangkap sebagai penanggungg jawab program lainnya. Walaupun sumber dana di peroleh dari APBD dan BOK, pihak Puskesmas menggunakan cara alternatif dalam lamanya proses pencairan dana dari APBD dan BOK dengan cara menggunakan uang 
kas Puskesmas maupun uang pribadi pemegang program itu sendiri. Kurangnya alat Fogging dalam sarana dan prasarana Puskesmas bengkalis membuat proses kegiatan fogging tidak maksimal.

Dalam pelaksanaan Kegiatan P2DBD, Kegiatan Penyelidikan Epidemiologi dilaksanakan apabila ada laporan dari pihak rumah sakit jika pasien terkonfirmasi terserang penyakit Demam Berdarah. Untuk Pelaksanaan Pemeriksaan Jentik Berkala pada tahun 2019 terjadi kendala dimana kegiatan PJB tidak berjalan dengan baik. Itu dikarenakan peran kader jumantik yang kurang maksumal. Kurangnya kegiatan Penyuluhan diakibatkan efek pandemi namun kegiatan fogging tetap dapat terlaksanakan.

\section{DAFTAR PUSTAKA}

BPS. (2018). Badan Pusat Statistik. Kecamatan Bengkalis: Badan Pusat Statistik.

Dinas Kesehatan Kab.Bengkalis. (2020).

Dinkes Kabupaten Bengkalis. (2013).

Depkes RI. 2005. Pencegahan dan Pemberantasan Demam Berdarah Dengue di Indonesia. Jakarta ; Departemen Kesehatan Republik Indonesia.

Depkes RI. 2007. Modul Pelatihan bagi Pengelolan program Pen gendalian Penyakit Demam Berdarah Dengue di Indonesia. Jakarta; Departemen Kesehatan Republik Indonesia.

Susanti L dan Boesri H. 2012. Insektisida Sipermethrin 100 G/L Terhadap Nyamuk Dengan Metode Pengasapan. Jurnal Kesehatan Masyarakat, 7 (2) 157-163.

European Centre for Disease Prevention and Control. (2020, January). Dengue Fever. Dengue worldwide overview.

Handoko, H. (2014). Hani Handoko, Manajemen , $h$ 8. Usman Effendi,
Asas Manajemen, Jakarta: Rajawali Pers, 2014, h.1. 19, 19-51.

Iskandar,

H.A., dkk. 2005. Pemberantasan Serangga dan Binatang pengganggu. Jakarta ; Balai Penerbit FKUI.

Julkifnidin. (2016). Analisis Pelaksanaan Program Pemberantasan DBD dan Tingkat Keberhasilan Pencegahan dan Pengendaliannya di Puskesmas Wilayah Kabupaten Kotawaringin Barat.

Kemenkes RI. (2019). Demam Berdarah . Kesiapsiagaan Menghadapi Peningkatan Kejadian Demam Berdarah Dengue Tahun 2019.

Kementrian Kesehatan RI. (2018). Demam Berdarah Dengue. InfoDatin Situas Demam Berdarah Dengue, 71-78.

Masriadi. (2017). Epidemiologi Penyakit Menular. Depok: Rajawali Pers

PermenkesRI. (2014). Peraturan Menteri Kesehatan Republik Indonesia. Penyelenggaraan Surveilans Kesehatan.

Peter Salim dan Yenni Salim . (2002). Kamus Bahasa Indonesia Kontemporer karangan Peter Salim dan Yenni Salim (2002). Journal of Chemical Information and Modeling, 1689-1699.

Profil Puskesmas Bengkalis. (2018). Profil Puskesmas Bengkalis Kecamatan Bengkalis. Bengkalis: Puskesmas Bengkalis .

Rahayu, T. (2012). Evaluasi Pelaksanaan Program Pencegahan dan Penanggulangan Penyakit Demam Berdarah Dengue di Wilayah Kerja Puskesmas Ketapang 2 (Studi di Kecamatan Mentawa Baru Ketapang Kabupaten Kotawaringin Timur Propinsi Kalimantan Tengah). Jurnal Kesehatan Masyarakat UNDIP, 479492. 
Sudarmayanti. (2001). Sumber Daya manusia dan Produktivitas Kerja. Madar maju, Bandung.

Sugiyono, S. (2019). BAB II Kajian Pustaka 2.1 Pengertian Analisis. FKIP Universitas Jambi, 12-38.

Susiawan, S. M. (2015). Kepemimpinan Transformasional, Kepuasan Kerja dan Komitmen Organisasi. Persona:Jurnal Psikologi Indonesia, 304-313.

wahyuni, T. (2018). Pemberdayaan Masyarakat Dalam Pengendalian Demam Berdarah Dengue (Literature Review). Jurnal Vektor Penyakit.

Zumaroh. (2015). Evaluasi Pelaksanaan Surveilans Kasus Demam Berdarah Dengue di Puskesmas Putat Jaya Berdasarkan Atribut Surveilans. Jurnal Berkala Epidemiologi, 82-94 